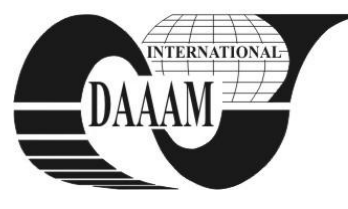

Annals of DAAAM for 2011 \& Proceedings of the 22nd International DAAAM Symposium, Volume 22, No. 1, ISSN 1726-9679 ISBN 978-3-901509-83-4, Editor B. Katalinic, Published by DAAAM International, Vienna, Austria, EU, 2011 Make Harmony between Technology and Nature, and Your Mind will Fly Free as a Bird Annals \& Proceedings of DAAAM International 2011

\title{
PRINCIPLES OF DESIGN FOR THE LIFE-CYCLE
}

\section{HRICOVA, B[eata]; NAKATOVA, H[enrieta] \& BADIDA, M[iroslav]}

\begin{abstract}
The industrial Revolution was devastatingin its environmental impact. As greater environmental concerns arose, designers, scientists, governments and eventually industrialists initiated efforts to address these problems. These efforts led to the creation, adoption ale practice of life-cycle engineering and design for environment programs.
\end{abstract}

Key words: design, life-cycle, sustainable development

\section{INTRODUCTION}

The purpose of DfLC is to create products that positively affect the environment, thus decreasing ecological damage. This is a broader aim than the elimination, reduction and prevention of waste. Each product life-cycle stage has its own guidelines or principles that come together to achieve this goal. Trade-offs among these stages, as well as between DfLC principles and other design objectives, must be balanced so that products are optimized for environmental performance over the entire life-cycle. DfLC principles can act in concert to better environmental performance; addressing one aspect of product efficiency can lead to efficiency improvements in other aspects.

\section{PRODUCT DESIGN PRINCIPLES}

The product design process cements many details of a product and hence determines many of the possibilities for how other life-cycle design principles can be applied (Tab. 1.). During the product design stage, designers must measure environmental performance iteratively and make design decisions accordingly. The cost of a product throughout its lifecycle must be predicted, including environment-related expenditures. Lastly, by increasing the useful life of a product with appropriate technical and aesthetic life spans in mind, designers can attain many environmental benefits (Kutz, 2007).

\begin{tabular}{|c|c|c|c|}
\hline \multicolumn{4}{|c|}{ WHO APPLIES } \\
\hline & Explanation & Principles & Example \\
\hline $\begin{array}{l}\text { Measure } \\
\text { Environmental } \\
\text { Performance }\end{array}$ & $\begin{array}{l}\text { Asses } \\
\text { resource } \\
\text { use and } \\
\text { risks }\end{array}$ & $\begin{array}{l}\text { Design } \\
\text { team }\end{array}$ & $\begin{array}{l}\text { Use life-cycle } \\
\text { assessment to } \\
\text { identify and } \\
\text { benchmark } \\
\text { environmental } \\
\text { impacts }\end{array}$ \\
\hline $\begin{array}{l}\text { Consider All } \\
\text { Costs }\end{array}$ & $\begin{array}{l}\text { Determine } \\
\text { all product } \\
\text { life-cycle } \\
\text { costs }\end{array}$ & $\begin{array}{l}\text { Design } \\
\text { team }\end{array}$ & $\begin{array}{l}\text { Employ life } \\
\text { cycle costing } \\
\text { to capture all } \\
\text { costs incurred } \\
\text { by a product }\end{array}$ \\
\hline $\begin{array}{l}\text { Minimize and } \\
\text { Eliminate }\end{array}$ & $\begin{array}{l}\text { Choose } \\
\text { design that } \\
\text { facilitates } \\
\text { recycling }\end{array}$ & $\begin{array}{l}\text { Design } \\
\text { team }\end{array}$ & $\begin{array}{l}\text { Upgrade the } \\
\text { technology in } \\
\text { a product, } \\
\text { improve } \\
\text { product } \\
\text { durability, or } \\
\text { employ } \\
\text { aesthetics that } \\
\text { people will } \\
\text { enjoy long- } \\
\text { term }\end{array}$ \\
\hline
\end{tabular}

Tab.1. Product Design Principles

\section{PACKAGING DESIGN PRINCIPLES}

The design of the product includes the design of packaging. Following environmentally responsible design principles such as those in Tab. 2. is an important step toward achieving environmentally benign packaging. Besides the product covering and marketing materials, all transportation packaging must be considered as well. (Mihok \& Liberkova, 2005) A good way to reduce packaging needs is for design and transportation engineers to communicate about product concerns and design packaging to fit both points of view. Setting up a deposit or refund for packaging or some type of return system between supplier, retailer, and user encourages packaging reuse.

\begin{tabular}{|c|c|c|c|}
\hline & \multicolumn{3}{|c|}{ WHO APPLIES } \\
\hline & Explanation & $\underset{\mathrm{s}}{\mathrm{P} \text { Principle }}$ & Example \\
\hline $\begin{array}{l}\text { Choose } \\
\text { Sustainably } \\
\text { Harvested } \\
\text { Materials }\end{array}$ & $\begin{array}{l}\text { Ensure that } \\
\text { renewable } \\
\text { resources } \\
\text { remain } \\
\text { available and } \\
\text { viable }\end{array}$ & $\begin{array}{l}\text { Design } \\
\text { team }\end{array}$ & $\begin{array}{l}\text { Pick } \\
\text { materials that } \\
\text { meet } \\
\text { sustainable } \\
\text { certification } \\
\text { requirements, } \\
\text { like wood } \\
\text { with the } \\
\text { Forest } \\
\text { Stewardship } \\
\text { Council label }\end{array}$ \\
\hline $\begin{array}{l}\text { Choose } \\
\text { Recyclabe } \\
\text { Materials }\end{array}$ & $\begin{array}{l}\text { Extend the } \\
\text { life of } \\
\text { materials } \\
\text { through } \\
\text { several } \\
\text { cycles }\end{array}$ & $\begin{array}{l}\text { Design } \\
\text { team }\end{array}$ & $\begin{array}{l}\text { Avoid using } \\
\text { composites; } \\
\text { instead } \\
\text { choose } \\
\text { materials } \\
\text { with } \\
\text { economically } \\
\text { viable } \\
\text { recycling } \\
\text { markets }\end{array}$ \\
\hline $\begin{array}{l}\text { Choose } \\
\text { Recycled } \\
\text { Materials }\end{array}$ & $\begin{array}{l}\text { Ensure that } \\
\text { recyclable } \\
\text { materials } \\
\text { have a } \\
\text { market }\end{array}$ & $\begin{array}{l}\text { Design } \\
\text { team }\end{array}$ & $\begin{array}{l}\text { Keep } \\
\text { recycled } \\
\text { material } \\
\text { quality high } \\
\text { for multiple } \\
\text { uses, use } \\
\text { recycled } \\
\text { materials in } \\
\text { their original } \\
\text { colors and } \\
\text { textures } \\
\end{array}$ \\
\hline $\begin{array}{l}\text { Avoid } \\
\text { Hazardous } \\
\text { Substances }\end{array}$ & $\begin{array}{l}\text { Ensure that } \\
\text { products are } \\
\text { safe for } \\
\text { human and } \\
\text { environmenta } \\
1 \text { health }\end{array}$ & $\begin{array}{l}\text { Design } \\
\text { team }\end{array}$ & $\begin{array}{l}\text { Choose } \\
\text { materials that } \\
\text { cause no } \\
\text { health or } \\
\text { legal } \\
\text { concerns }\end{array}$ \\
\hline
\end{tabular}




\begin{tabular}{|c|c|c|c|}
\hline $\begin{array}{l}\text { Reduce } \\
\text { Material } \\
\text { Process } \\
\text { Energy }\end{array}$ & $\begin{array}{l}\text { Account for } \\
\text { material } \\
\text { production } \\
\text { effects in the } \\
\text { environmenta } \\
\text { l impact of a } \\
\text { product }\end{array}$ & $\begin{array}{l}\text { Material } \\
\text { producer } \\
\mathrm{s} \text { and } \\
\text { design } \\
\text { team }\end{array}$ & $\begin{array}{l}\text { Consider the } \\
\text { energy and } \\
\text { impact } \\
\text { differences } \\
\text { for producing } \\
\text { materials at a } \\
\text { facility } \\
\text { instead of } \\
\text { outsourcing } \\
\text { the finished } \\
\text { substances } \\
\text { before } \\
\text { making } \\
\text { manufacturin } \\
\text { g changes }\end{array}$ \\
\hline $\begin{array}{l}\text { Eliminate } \\
\text { Material } \\
\text { Waste }\end{array}$ & $\begin{array}{l}\text { Decrease the } \\
\text { amount of } \\
\text { material that } \\
\text { becomes } \\
\text { waste during } \\
\text { production }\end{array}$ & $\begin{array}{l}\text { Design } \\
\text { team }\end{array}$ & $\begin{array}{l}\text { Design } \\
\text { products to } \\
\text { make } \\
\text { manufacturin } \\
\text { g offcuts as } \\
\text { small as } \\
\text { possible }\end{array}$ \\
\hline $\begin{array}{l}\text { Dematerializ } \\
\text { e }\end{array}$ & $\begin{array}{l}\text { Remove } \\
\text { materials } \\
\text { from a } \\
\text { product }\end{array}$ & $\begin{array}{l}\text { Design } \\
\text { team }\end{array}$ & $\begin{array}{l}\text { Reduce the } \\
\text { weight and } \\
\text { volume of } \\
\text { materials in a } \\
\text { product }\end{array}$ \\
\hline $\begin{array}{l}\text { Simply } \\
\text { Products }\end{array}$ & $\begin{array}{l}\text { Eliminate the } \\
\text { material } \\
\text { waste of } \\
\text { overdesign }\end{array}$ & $\begin{array}{l}\text { Design } \\
\text { team }\end{array}$ & $\begin{array}{l}\text { Eliminate } \\
\text { features that } \\
\text { are not } \\
\text { essential or } \\
\text { necessery for } \\
\text { a product to } \\
\text { function or } \\
\text { combine } \\
\text { features }\end{array}$ \\
\hline $\begin{array}{l}\text { Choose } \\
\text { Cleaner } \\
\text { Production } \\
\text { Processes }\end{array}$ & $\begin{array}{l}\text { Select the } \\
\text { production } \\
\text { processes } \\
\text { with least } \\
\text { environmenta } \\
\text { l impact }\end{array}$ & $\begin{array}{l}\text { Manufac } \\
\text {-turers }\end{array}$ & $\begin{array}{l}\text { Empoly lean } \\
\text { manufacturin } \\
\mathrm{g} \text { techniques } \\
\text { to remove } \\
\text { inefficiencies } \\
\text { and waste } \\
\text { from } \\
\text { production } \\
\text { and choose } \\
\text { suppliers that } \\
\text { use the most } \\
\text { benign } \\
\text { methods }\end{array}$ \\
\hline $\begin{array}{l}\text { Choose } \\
\text { Clean Power } \\
\text { Sources }\end{array}$ & $\begin{array}{l}\text { Utilize power } \\
\text { sources that } \\
\text { create the } \\
\text { least } \\
\text { pollution }\end{array}$ & $\begin{array}{l}\text { Manufac } \\
\text {-turers }\end{array}$ & $\begin{array}{l}\text { Use } \\
\text { renewable } \\
\text { energy like } \\
\text { wind power } \\
\text { to generate } \\
\text { needed } \\
\text { electricity }\end{array}$ \\
\hline
\end{tabular}

Tab.2. Material Design Considerations

\section{PRODUCT USE DESIGN PRINCIPLES}

The use phase of a product can also contribute significantly to its impact. Designers are responsible for improving the energy efficiency of products. However, ensuring that products are safe for users and their environment is also important for meeting DfLC principles. The principles in Tab. 3. highlight some of the general do and don ts that a product designer can control with respect to the environmental impact of product use.

\begin{tabular}{|l|l|l|l|}
\hline & \multicolumn{3}{|c|}{ WHO APPLIES } \\
\hline & Explanation & Principles & Example \\
\hline $\begin{array}{l}\text { Recude } \\
\text { Product } \\
\text { Energy }\end{array}$ & $\begin{array}{l}\text { Improve } \\
\text { product } \\
\text { energy } \\
\text { efficiency to } \\
\text { reduce waste } \\
\text { and } \\
\text { emissions }\end{array}$ & Design team & $\begin{array}{l}\text { Fix leaks or } \\
\text { energy losses } \\
\text { and inform } \\
\text { consumers } \\
\text { how to best } \\
\text { use products }\end{array}$ \\
$\begin{array}{l}\text { Keep } \\
\text { Products }\end{array}$ & $\begin{array}{l}\text { Create } \\
\text { products that } \\
\text { do not emit } \\
\text { pollutants }\end{array}$ & Design team & $\begin{array}{l}\text { Substitute } \\
\text { materials } \\
\text { used in } \\
\text { adhesives to } \\
\text { stop product } \\
\text { off-gassing }\end{array}$ \\
\hline
\end{tabular}

Tab. 3. Product Use Design Principles

\section{PRODUCT END-OF-LIFE DESIGN PRINCIPLES}

At the end of a products useful life, end-of-life systems for the collection of broken or unwanted products must be initiated in place. Designing for product take-back and establishing a unique product take-back system increases the chances of a product being reused, remanufactured or recycled. Sometimes users discard the whole product when only one component fails, so designing all product components to fails at the same time can create less waste. Many end-of-life options exist for products; each has its own advantages and disadvantages.

\section{CONCLUSION}

There are additional principles that lead to radically new ways in which DfLC can be realized. These principles fit in several broad categories. Using nature as inspiration for product design can lead to reduced environmental impact. Users can also enjoy the function of a product without possessing an object, reducing the necessary production volume while increasing utilization. Designing in multiple life-cycles or industrial ecosystems is another worthy goal (Muransky \& Badida, 2005). Designing for sustainability incorporates DfLC principles as well as social and economic concerns, a challenge that corporations and designers recognize as designing for the triple bottom libne. All of these product design principles stretch the generally held body of thinking behind DfLC.

The paper was elaborated in connection with the projects KEGA, No. 3/7422/09 - Creating of research conditions for preparation of modern university textbook - Ecodesign in Mechanical Engineering, solved at the Department of Environmental Studies, Faculty of Mechanical Engineering at the Technical University in Košice.

\section{REFERENCES}

Kutz, M.(2007): Environmentally Conscious Mechanical Design. Library of Congress Cataloging, USA, 2007, pp.381, ISBN 13 978-0-471-72636-4

Muranský, J.- Badida, M.(2005): Ekodizajn v strojárstve. Základy metodiky. Technická univerzita v Košiciach, Vydavatel'stvo Michala Vaška, Prešov, 2005, 304 s., ISBN 80-8073-119-5

Mihók, J., Liberkova, L. (2005): Vyhodnocovanie efektívnosti znižovania miery zat’aženosti ŽP. In: Moderné prístupy k manažmentu podniku, Bratislava, STU, 2005, s. 360-363, ISBN80-227-2284-7 